\title{
PENGARUH SUBTITUSI TEPUNG BERAS MERAH KOMBINASI UBI JALAR UNGGU TERHADAP MUTU PANCAKE
}

\author{
Desi Arisanti ${ }^{1)}$, Syaiful Umela ${ }^{2)}$ \\ 1. Dosen Program Studi Teknologi Hasil Pertanian, Politeknik Gorontalo \\ 2. Dosen Program Studi Teknologi Hasil Pertanian, Politeknik Gorontalo \\ J1. Muchlis Rahim Desa Panggulo, Kec. Botupingge Kab. Bone Bolango, Provinsi Gorontalo \\ Email: desiarisanti47@gmail.com ${ }^{1)}$
}

\begin{abstract}
ABSTRAK
Beras merah merupakan jenis beras yang memiliki warna merah. Warna merah dari beras merah ditimbulkan oleh pigmen antosianin yang terdapat pada bagian lapisan luarnya. Penelitian ini bertujuan untuk mengetahui tingkat kesukaan pancake dan untuk mengetahui kandungan nutrisi pancake. Parameter yang digunakan dalam uji tingkat kesukaan yaitu warna, rasa, aroma dan tekstur. Sedangkan untuk analisa sifat kimia yaitu kadar air, kadar lemak, kadar abu, dan kadar total gula. Penelitian ini menggunakan metode Rancangan Acak Lengkap (RAL) dengan tiga perlakuan dengan tiga kali ulangan. Hasil penelitian menunjukkan bahwa tingkat kesukaan penerimaan panelis untuk perlakuan terbaik adalah perlakuan A1 (500 g tepung beras merah), yaitu warna 3,77\%; rasa 4,00\%; aroma 3,8\%; dan tekstur 3,77\%. Adapun hasil analisa sifat kimia dari pancake tepung beras merah adalah kadar air A1 54,67\%; kadar lemak 4,88\%; kadar abu 1,03\%; dan kadar total gula 10,40\%.

Dari data hasil penelitian tingkat kesukaan dan analisis kimia pancake tepung beras merah, dapat ditarik kesimpulan bahwa pada skala 3,53\% - 4,00\% atau dalam taraf biasa sampai suka, dan pancake tepung beras merah yang paling disuka adalah A1. Dan dari data hasil analisis kimia pancake tepung beras merah dapat ditarik kesimpulan bahwa perlakuan yang paling disuka adalah perlakuan A1 (500 g tepung beras merah).
\end{abstract}

Kata Kunci : Pancake, Tepung Beras Merah, Ubi Jalar Ungu

\section{ABSTRACT}

Brown rice is a type of rice that has a red color. The red color of brown rice is caused by the anthocyanin pigment found on the outer layer. This study aims to determine the level of favorite pancakes and to determine the nutritional content of pancakes. Parameters used in the favorite test are color, taste, aroma and texture. As for the analysis of chemical properties such as moisture content, fat content, ash content, and total sugar content. This study used the Completely Randomized Design (RAL) method of three treatments with three replications. The results showed that the preferred level of panelist reception for the best treatment was Al treatment (500 g of red rice flour), ie $3.77 \%$ color; taste of $4.00 \%$; $3.8 \%$ odor; and $3.77 \%$ texture. The result of chemical properties analysis of red rice flour pancake is water content A1 54,67\%; 4.88\% fat content; ash content 1.03\%; and total sugar content of $10.40 \%$. The research data of the favorite level and the chemical analysis of red rice flour pancake, it can be deduced that on the scale of 3.53\% - 4.00\% or in the usual level until likes, and the most preferred red rice flour pancake is A1. And from the results of chemical analysis of red rice flour pancake can be concluded that the preferred treatment is the treatment of Al (500 $\mathrm{g}$ of brown rice flour).

Kata Kunci : Pancake, Tepung Beras Merah, Ubi Jalar Ungu

\section{PENDAHULUAN}

Produk pangan yang menggunakan bahan baku tepung terigu atau gandum, menjadI kesempatan untuk mengurangi konsumsi terigu dengan cara mengganti tepung selain gandum. Salah satunya adalah tepung beras merah yang merupakan bahan pangan lokal. Beras merah adalah tanaman jenis padi-padian yang berwarna kemerahan, beras merah merupakan tanaman tahunan yang melimpah di Indonesia. Padi beras merah tergolong dalam family Gramineae, sub famili Oryzaidae, suku / genus dan spesies oryza sativa. Kandungan gizi beras merah per $100 \mathrm{~g}$; terdiri atas protein 7,5 g; lemak $0,9 \mathrm{~g}$; karbohidrat 77,6 g; kalsium $16 \mathrm{mg}$; fosfor $16 \mathrm{mg}$; zat besi 0,3; vitamin B1 0,21 mg dan antosianin. Antosianin adalah senyawa fenolik yang masuk kelompok flavonoid yang berperan penting, baik bagi tanaman itu sendiri maupun bagi kesehatan manusia (Wijayanti, 2015). 
Pada umumnya beras merah biasanya hanya dikonsumsi oleh orang yang mempunyai penyakit diabetes dan kolestrol tinggi sebagai makanan pokok seperti nasi. Beras merah dapat dijadikan macam-macam produk makanan yang disukai berbagai kalangan seperti pancake. Karena pancake juga bagus untuk orang yang ingin atau sedang melakukan diet, meskipun dikonsumsi dalam jumlah yang banyak pancake berbahan dasar tepung beras merah ini tidak menyebabkan kegemukaan. Pancake merupakan hidangan yang memiliki rasa manis dan gurih dari adonan batter yang dipanggang dengan frying pan serta berbentuk bulat dan pipih. Adonan batter merupakan adonan cair yang terdiri dari tepung terigu, telur, bahan cair (air atau susu) dan bahan pengembang yang diaduk sehingga teremulsi dan dimatangkan dengan teknik memanggang (Amarilia, 2012 dalam Pipit, 2015).

Ubi jalar ungu merupakan sumber karbohidrat dan sumber kalori yang cukup tinggi. Ubi jalar ungu juga merupakan sumber vitamin dan mineral, vitaminyang terkandung dalam ubi jalar antara lain Vitamin A, Vitamin C, Thiamin (vitamin B1) dan Ribovlavin. Sedangkan mineral dalam ubi jalar diantaranya adalah zat besi (Fe), fosfor $(\mathrm{P})$ dan kalsium (Ca). Total kandungan antosianin bervariasi pada setiap tanaman dan berkisar antara $20 \mathrm{mg} / 100$ $\mathrm{g}$ sampai $600 \mathrm{mg} / 100 \mathrm{~g}$ berat basah. Total kandungan antosianin ubi jalar ungu adalah 519 $\mathrm{mg} / 100 \mathrm{~g}$ berat basah (Iriyanti, 2012 dalam Pipit, 2015).

Dalam penelitian ini akan ditambahkan atau dicampurkan ubi jalar ungu dengan perbandingan tepung beras merah dalam pembuatan pancake. Karena hal ini dilakukan untuk mengetahui perbandingan yang tepat untuk menghasilkan tekstur yang banyak disukai oleh panelis berdasarkan uji kesukaan terhadap pancake. Oleh sebab itu, peneliti melakukan penelitian yang berbahan dasar beras merah dan ubi jalar ungu dalam pembuatan pancake.

\section{METODE PENELITIAN}

Alat yang digunakan dalam penelitian yaitu : mesin penggiling tepung, timbangan analitik, wadah, ayakan, panci, kompor, wajan, gelas ukur, desikator, oven, cawan petri, cawan porselin, tabung reaksi, timbangan digital, mixer, tanur, sendok, teflon, penjepit cawan, mortal, spatula, soxhslet, becer $300 \mathrm{~mL}$.

Bahan dalam proses pembuatan pancake antara lain: tepung beras merah, ubi jalar ungu, garam, air, telur, ragi, susu, mentega, aquades, tisu.

\section{Proses Pembuatan Pancake \\ Proses Pembuatan pancake melalui dua tahap, yaitu:}

- Proses pembuatan tepung beras merah (Herawati, 2012)

- Direndam beras merah dalam wadah selama 24 jam pada suhu ruang

- Dicuci bersih beras dari air rendaman lalu tiriskan hingga kering, diangin-anginkan diatas saringan kawat lalu jemur sebentar atau keringkan dengan hair dryer.

- Beras merah digiling menggunakan penggilingan discmill menggunakan ayakan 48 mesh.

- Setelah proses penggilingan beras merah dikeringkan kembali dengan dijemur/ dioven agar tepung beras merah lebih awet.

- $\quad$ Proses Pembuatan Pancake (Rizqi, 2013)

- Dicampur rata dan aduk tepung beras merah, garam, kuning telur, dan susu dengan mengunakan mixer dengan kecapatan rendah

- Dikocok putih telur samapai kaku

- Kemudian dimasukan adonan tepung beras merah dan ubi jalar ungu yang sudah dikukus ke dalam adonan putih telur, aduk rata.

- Dicampur adonan tepung beras merah dengan putih telur, bias juga menggunakan teknik pancing dengan cara mengambil sedikt putih telur dan campurkan ke dalam tepung beras merah aduk rata.

- Dipanaskan teflon diameter paling kecil.

- Dioleskan dengan margarin.

- Kemudian dituang adonan ke dalam Teflon lalu tutup sebentar

- Balik jika adonan sudah ada sedikit berpori dan sedikit mengeras pinggirnya.

- Pancake siap disajikan.

\section{HASIL DAN PEMBAHASAN}

\subsection{Tingkat Kesukaan}

Tingkat kesukaan pancake tepung beras merah untuk melihat produk yang disukai oleh panelis pada penelitian ini ditentukan oleh uji organoleptik mengunakan uji hedonik. Penilaian dilakukan meliputi empat parameter pengamatan yaitu warna, rasa, aroma, dan tekstur.

Analisis organoleptik yang digunakan pada penentuan formulasi pancake tepung beras merah yang menggunakan skala penerimaan 1 sampai 5. Pengujian ini dilakukan oleh 30 orang panelis yang tidak terlatih, dan parameter yang dinilai meliputi: 1) rasa; 2) aroma; 3) tekstur; dan warna.

\subsubsection{Warna}

Penentuan mutu bahan pangan pada umumnya sangat bergantung pada beberapa faktor, diantaranya cita rasa, warna tekstur dan aroma. Tetapi faktor warna tampil lebih dulu dan sangat menentukan (Winarno, 2008). Warna produk pangan sangat menentukan penerimaan penolakan konsumen terhadap produk tersebut. 


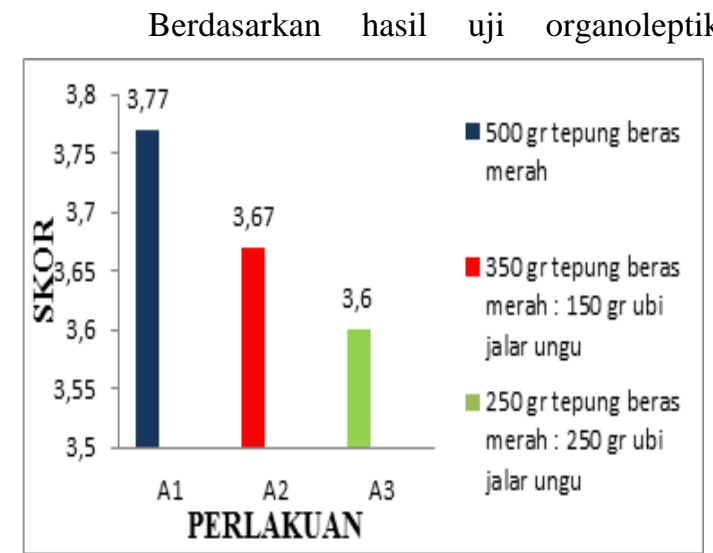

terhadap parameter warna dapat dilihat pada Gambar 1

Gambar 1. Grafik tingkat kesukaan warna

Berdasarkan diagram hasil penguji terhadap pancake tepung beras merah menunjukkan bahwa tingkat penerimaan panelis terhadap parameter warna menunjukkan nilai berkisar 3,6 sampai 3,77 ini masih berkisar taraf netral. Pancake tepung beras merah yang tertinggi pada perlakuan A1 (500 gram tepung beras merah tanpa penambahaan ubi jalar ungu), karena A1 tidak ada penambahan ubi jalar ungu atau hanya menggunakan tepung beras merah.

\subsubsection{Rasa}

Rasa sangat menentukan penerimaan konsumen terhadap prodak pangan. Menurut Winarno (2008), indera pencicipan dapat menyebabkan empat macam rasa yang utama, rasa asin, asam, manis, dan

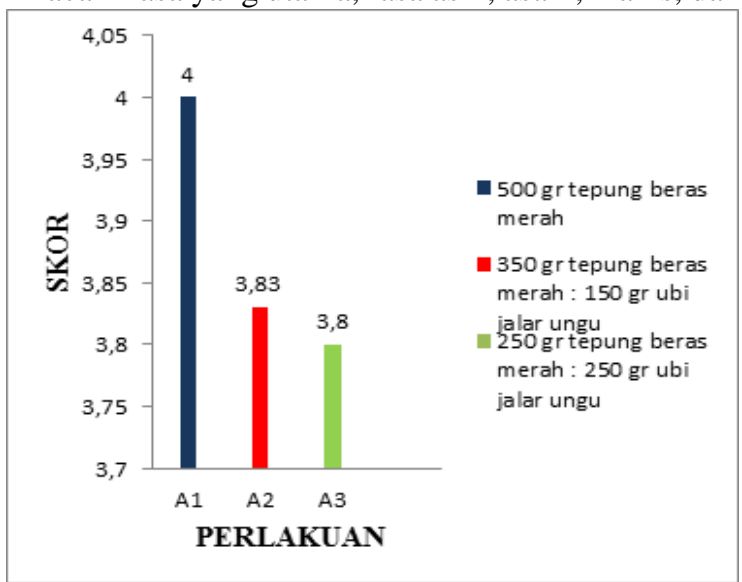

pahit. Hasil uji organoleptik terhadap parameter rasa pancake dapat dilihat pada Gambar 2.

Gambar 2. Grafik tingkat kesukaan rasa.

Berdasarkan hasil uji organoleptik terhadap pancake tepung beras merah menujukan tingkat penerimaan panelis sangat berbeda jauh atau masih dalam taraf netral hingga suka. Dari ketiga perlakuan yang memiliki nilai tertinggi atau yang sangat di minati oleh panelis pada parameter rasa yakni perlakuan A1 dapat dilihat pada Gambar 6. Ini karena pada perlakuan A1 lebih dominan tepung beras merah. Sedangkan pada perlakuan A3 perbandingannya sama(250 g tepung beras merah : 250 ubu jalar ungu).

\subsubsection{Aroma}

Aroma makanan umumnya menentukan kelezatan bahan makanan dan banayak berhubungan dengan indra penciuman. (Winarno, 2008).

Hasil uji organoleptik terhadap parameter aroma dapat dilihat pada Gambar 3.

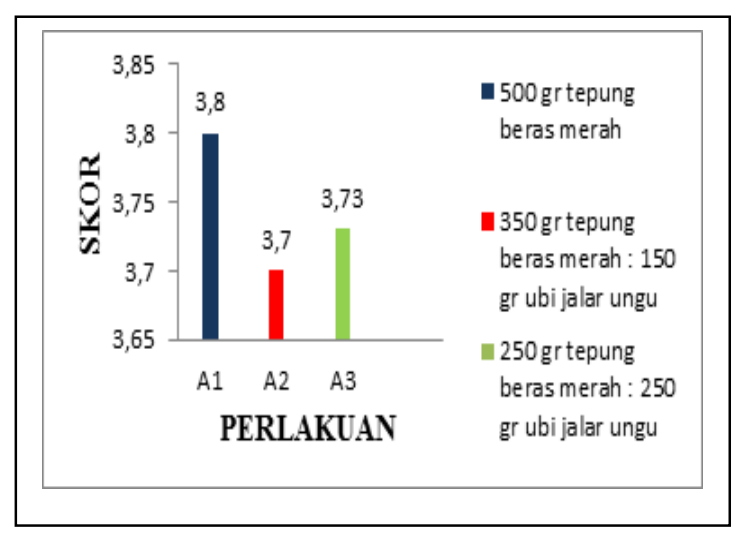

Gambar 3. Grafik tingkat kesukaan rasa.

Berdasarkan hasil uji organoleptik terhadap aroma pancake tepung beras merah menujukan bahwa nilai tingkat penerimaan panelis terhadap parameter aroma menujukan nilai berkisar antara 3,7 sampai 3,8 atau dalam taraf netral. pada perlakuan A1 dapat di lihat dari gambar di atas memiliki nilai paling tinggi yaitu 3,8. Sedangakan yang memiliki nilai terendah terdapat pada perlakuan A2 yang menggunakan 350 gram tepung beras merah dengan perbandingan 150 gram ubi jalar ungu. Untuk sampel A3 dia tidak beda jauh dari perlakuan A1 karena mengunakan pebandingan 250 gram tepung beras merah dan 250 gram ubi jalar ungu.

\subsubsection{Tekstur}

Tekstur adalah faktor kualitas makanan yang paling penting, oleh karena itu konsumen menghendaki makanan mempunyai rasa dan tekstur yang sesuai dengan selera yang meraka harapkan. Jika konsumen memberi makanan, maka pentingnya nilai gizi biasanya ditempatkan pada mutu setelah harga, tekstur, dan rasa (Pancawati, 2015). Hasil uji organoleptik terhadap parameter tekstur dapat dilihat pada Gambar 4. 


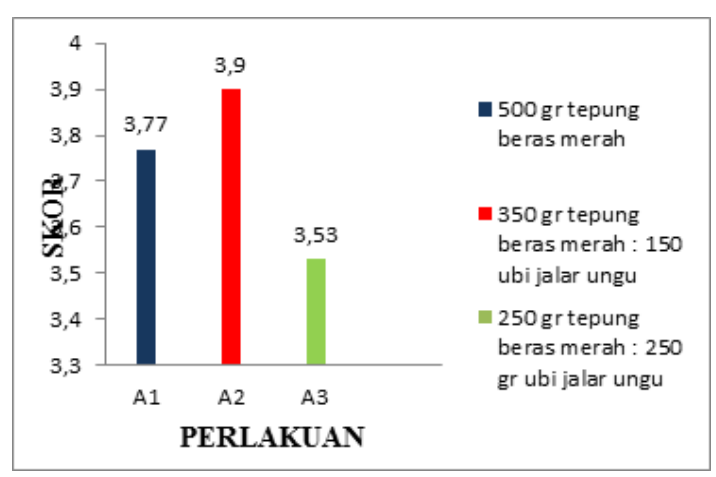

Gambar 4. Grafik Tingkat Kesukaan Tekstur

Berdasarkan hasil uji organoleptik terhadap tekstur pancake tepung beras merah menujukan bahwa nilai tingkat penerimaan panelis terhadap parameter tekstur menujukan nilai berkisar antara 3,53 sampai 3,9 atau dalam taraf netral. Pada perlakuan A2 dapat dilihat dari gambar diatas memiliki nilai paling tinggi yaitu 3,9 yakni dengan perbandingan (350 $\mathrm{g}$ tepung beras merah : $150 \mathrm{~g}$ ubi jalar ungu).

\subsection{Analisa Sifat Kimia}

\subsubsection{Kadar air}

Kadar air merupakan komponen penting dalam bahan pangan yang dapat mempengaruhi kualitas bahan. Penurunan jumlah air dapat mempengaruhi laju kerusakan bahan pangan akibat kerusakan mikrobiologis, kimiawi dan enzimatis. Rendahnya kadar air suatu bahan pangan merupakan salah satu faktor yang dapat membuat bahan pangan menjadi awet. Proses pengurangan kadar air dapat dilakukan dengan proses pengeringan ataupun proses penggorengan. Pada proses pengeringan, kandungan air dikurangi dengan cara menguapkan air pada bahan menggunakan energi panas, sedangkan pada proses penggorengan terjadi penghilangan air dalam jumlah yang besar dari bahan pangan dan terjadi penyerapan minyak ke dalam bahan pangan (Andarwulan, 2011).

Nilai rata-rata kadar air pancake tepung beras merah dapat dilihat pada Tabel 1 .

Tabel 1. Nilai rata-rata kadar air pancake tepung beras merah

Berdasarkan analisis sidik ragam kadar air pada pada Gambar 10, bahwa $F_{\text {hitung }}$ (193.69) lebih besar dari $F_{\text {tabel }}(0,05)$ yaitu 5.14 dan $F_{\text {tabel }}$ $(0,01)$ yaitu 10.92 , hasil sidik ragam menunjukan bahwa perbedaan perlakuan pada pembuatan pancake tepung beras merah sangat berpengaruh nyata terhadap kadar air yang diperoleh, sehingga dilakukan uji lanjut BNT. Hasil uji lanjut BNT menunjukkan bahwa pancake tepung beras merah pada perlakuan A1 sangat berbeda nyata dengan perlakuan A2 dan A3. Perlakuan A3 memiliki kadar air tertinggi yaitu 88.78 dan A2 memiliki kadar air yaitu 74.46 dan A1 memiliki kadar air terendah yaitu 54.67. Hal ini disebabkan oleh kandungan kadar air pada ubi jalar ungu sangat tinggi yaitu 55,23\% sedangkan kadar air yang dimiliki oleh tepung beras merah yaitu $4.79 \%$. Kadar air berpengaruh pada stabilitas suatu material pada saat disimpan. Apabila suatu bahan memiliki kadar air yang tinggi, maka ketahanan pada saat penyimpanan rendah sehingga mudah rusak saat disimpan (Nielsen, 2003).

\subsubsection{Kadar Lemak}

Lemak yang diperlukan oleh manusia adalah asam lemak esensial, yaitu asam lemak yang tidak dapat disintesis oleh tubuh sehingga harus disuplai dari pangan, misalnya asam oleat, asam linoleat dan asam linolenat (Kusnandar, 2001).

Hasil analisa rata-rata kadar lemak pancake tepung beras merah dari ketiga perlakuan dengan tiga kali ulangan dapat dilihat pada Tabel 2 sebagai berikut.

\begin{tabular}{cc}
\hline Kode Sampel & Rata-Rata \\
\hline A1 & 4.88 \\
A2 & 5.23 \\
A3 & 5.20 \\
\hline Tabel 2. Nilai rata-rata kadar lemak pancake tepung beras merah
\end{tabular}

Berdasarkan analisis sidik ragam dapat diketahui bahwa rata-rata kadar lemak pancake tepung beras merah pada A1 yaitu $4.88 \%$, A2 yaitu $5.23 \%$, A3 yaitu $15.20 \%$. kadar lemak yang tertinggi yaitu pada perlakuan A2 sedangkan nilai kadar lemak terendah yairu ada perlakuan A1. Hal disebabkan pada perlakuan A2 formulasi tepung beras meprah lebih tinggi dari perlakuan A1 dan A3 tepung beras merah mengandung protein dan berbagai asam amino, asam lemak tidak jenuh (12\%) dan sterol yang dapat mengurangi sintesis kolesterol dalam hati. Asam lemak tidak jenuh sangat esensial sebagai obat antitrombotik dan hipolepidemik. Selain itu asam linolenat mampu menurunkan lipoprotein densitas rendah (LDL) bagi penderita hiperkolesterolemia (berisiko jantung koroner) serta mengobati sindrom prahaid dan eksemenia atopik (Rahmat, 2000).

Berdasarkan hasil analisa sidik ragam,

\begin{tabular}{cc}
\hline Kode Sampel & Rata-rata (\%) \\
\hline A1 & 54.67 \\
A2 & 76.46 \\
A3 & 88.78
\end{tabular}

diperoleh bahwa nilai $F_{\text {hitung }}(0,21)$ lebih kecil dari $F_{\text {tabel }}(0,05)$ yaitu 5.14 dan $F_{\text {tabel }}(0,01)$ yaitu, artinya bahwa perlakuan pada pembuatan pancake tepung beras merah tidak berbeda nyata terhadap kadar lemak yang diperoleh. 


\subsubsection{Kadar Abu}

Penentuan kadar abu dapat ditentukan berbagai tujuan, antara lain untuk menentukan baik atau tidaknya suatu pengolahan, mengetahui jenis bahan yang digunakan dan sebagai penentu nilai gizi suatu bahan makanan (Jufri, 2016).

Hasil analisa rata-rata kadar abu pancake tepung beras merah dari ketiga perlakuan dengan tiga kali ulangan dapat dilihat pada Tabel 3.

\begin{tabular}{cc}
\hline Kode Sampel & Rata-Rata \\
\hline A1 & 1.03 \\
A2 & 1.13 \\
A3 & 1.18 \\
\hline
\end{tabular}

Tabel 3. Nilai rata-rata kadar abu pancake tepung beras merah

Berdasarkan Tabel di atas diketahui bahwa rata-rata kadar abu pancake tepung beras merah pada A1 yaitu $1.03 \%$, A2 yaitu $1.13 \%$, A3 yaitu $1.18 \%$ tingginya kadar abu pada A3 dibandingkan A1 dan A2 karena penggunaan tepung beras merah dan ubi jalar ungu pada A3 konsentrasinya sama dibandingkan pada A1 dan A2. Sehingga menyebabkan kandungan abu pada perlakuan A3 lebih tinggi dibandingkan yang lain.

Berdasarkan hasil analisa sidik ragam, diperoleh bahwa nilai $F_{\text {hitung }}(1,70)$ lebih kecil dari $F_{\text {tabel }}(0,05)$ yaitu 5.14 dan $F_{\text {tabel }}(0,01)$ yaitu, artinya bahwa perlakuan pada pembuatan pancake tepung beras merah tidak berbeda nyata terhadap kadar abu yang diperoleh. Hal ini di sebabkan oleh kadar abu pada ubi jalar ungu relativ sedikit yaitu 3,28\% (Widjanarko, 2008) dan kandung mineral pada beras merah yang relatif sedikit yaitu fosfor $163 \%$, besi 0,3\%, kalsium 16\% (Lansu, 2009). Sehingga kadar abu yang dihasilkan dari masing-masing perlakuan rendah.

\subsubsection{Kadar Total Gula}

Nilai rat-rata total gula pancake tepung beras merah dari ketiga perlakuan dengan tiga kali ulangan analisa dapat dilihat pada Tabel 4 sebagai berikut.

\begin{tabular}{cc}
\hline Kode Sampel & Rata-Rata \\
\hline A1 & 10.40 \\
A2 & 14.40 \\
A3 & 15.47 \\
\hline
\end{tabular}

Tabel 4. Nilai rata-rata total gula pancake tepung beras merah

Dilihat dari Tabel di atas, skor rata-rata total gula pancake tepung beras merah berkisar antara $10.4 \%-15.47 \%$. Berdasarkan analisa sidik ragam yang dilakukan, nilai $\mathrm{F}_{\text {hitung }}(10,7)$ lebih besar dari $F_{\text {tabel }}(0,05)$ yaitu 5.14 dan $F_{\text {tabel }}(0,01)$ yaitu 10.92, hasil sidik ragam menunjukan bahwa perbedaan perlakuan pada pembuatan pancake tepung beras merah berpengaruh nyata terhadap kadar gula yang diperoleh, sehingga dilakukan uji lanjut BNT. Hasil uji lanjut BNT menunjukkan bahwa pancake tepung beras merah pada perlakuan A1 sangat berbeda nyata dengan perlakuan A3, sedangkan perlakuan A2 tidak berbeda nyata dengan perlakuan A3. Hal ini disebabkan karena Dan perlakuan A3 memiliki kadar total gula tertinggi yaitu $15.47 \%$ dan disusul A2 memiliki kadar total gula yaitu $14.4 \%$ dan A1 memiliki kadar total gula terendah yaitu $10.4 \%$. karena pada perlakuan A3 lebih banyak penambahan ubi jalar ungu sehingga kadar gula pada perlakuan A3 lebih tinggi dari pada perlakuan A2 dan A1. Karena kandungan gula reduksi pada ubi jalar ungu yaitu $1.79 \%$ (Widjanarko, 2008).

\section{KESIMPULAN}

Berdasarkan hasil penelitian yang telah dilakukan terhadap pancake tepung beras merah pada 3 perlakuan, maka diperoleh kesimpulan sebagai berikut:

1. Tingkat kesukaan yang dihasilkan dari tiga perlakuan pancake tepung beras merah pada skala 3,53\% - 4,00\% atau dalam taraf biasa sampai suka. Dan pancake tepung beras merah yang paling disuka adalah perlakuan A1 (500 g tepung beras merah).

2. Perlakuan A1 adalah perlakuan terbaik karena memiliki kandungan kimia terbaik dari ketiga perlakuan yaitu kadar air 54,67\%; kadar abu $1,03 \%$; kadar lemak 1,88\%; dan kadar total gula $10,40 \%$.

\section{DAFTAR PUSTAKA}

Ahuja, Magnanti, Orlin. 2007.Red Rices: past, present, and future, Asian Agri- History 11, 4,Hal.291-304.

Andarwulan, N., F. Kusnandar \& D. Herawati. 2011. Analisis Pangan Pangan. Dian Rakyat, Jakarta.

Husni, Amarilia. 2011.Penelitian Studi Penggunaan Tepung Sukun Sebagai Bahan Pengganti Sebagian Tepung Pada Pembuatan Pancake Dan Bakpao.

Damanhuri. 2005. Pewaris Ananosianin dan Tanggap Klon Tanaman Ubi Jalar (Ipomeabatatas (L.) Lamb) terhadap Lingkungan Tumbuh. (Disertasi) Program Studi Ilmu Pertanian Program Pascasarjana Universitas Brawijaya. 106 h. Malang.

Herawati. H. 2012. Teknologi Proses Produksi Food Ingredient Dari Tapioka Termodifikasi. Balai Besar Penelitian Dan Pengembangan Pasca Panen Pertanian. Bogor. 
Jufri, I. 2016. Pengaruh Level Getah Pepaya Kering dan Suhu Pemanasan Terhadap Kualitas Kimia Dangke. Skripsi. Fakultas peternakan. Makassar. Universitas Hasanuddin.

Kusnandar, F. 2001. Kimia Pangan. Dian Rakyat. Jakarta.

Lansu. M.A. 2009. Penyuluhan Pertanian Magelang . Jurnal Ilmu Pertanian Sekolah Tinggi Yogyakarta

Maekawa, M. 1998. Recent information onanthocyanin pigmentation, Rice Genetics Newsletter 13, Hal. 25-26.

Marwanti. 2000. Pengetahuan Masakan Indonesia. Yogyakarta: Adicita Karya Nusa.

Mulyatiningsih, Endang. 2007. Diklat Teknik-teknik Dasar Memasak: Universitas Negeri Yogyakarta. Yogyakarta.

Nielsen, S. Suzanne, (2003), Food Analysis $3^{\text {rd }}$ ed., Kluwer Academic / Plenum Publishers, New York

Nintami, A. L. 2012. Kadar serat, Aktivitas Antioksidan, Amilosa dan Uji kesukaan Mi Basah Dengan Subtitusi Teoung Ubi Jalar Ungu (Ipomoea batatas) Bagi penderita diabetes mellitus Tipe-2. Program Studi Ilmu Gizi. Fakultas Kedokteraan. Universitas Diponegoro Semarang. Semarang.

Pastiniasih. 2011. Menguji Organoleptik. Bagian Proyek pengembangan Kurikulum. Direktorat Jendral Pendidikan Dasar dan Menengah Departemen Pendidikan Nasional. Jakarta.

Pancawati, A. 2015. Kualitas Dangke Pada Pengunaan Berbagai Produk Susu Cair Komersial Sebagai Bahan Baku. Skripsi. Program Studi Peternakan, Fakultas Peternakan. Makassar : Universitas Hasanuddin.

Utomo, AP. 2015. Eksperimen Pembuatan Pancake Komposit Tepung Ubi Jalar Ungu dengan Penambahan Sari Bit. Skripsi. Pendidikan Kesejahteraan keluarga. Fakultas Teknik Universitas Semarang. Semarang.

Rahmat, A. 2000. Produksi asam lemak tak jenuh majemuk dari Absidia corymbifera melalui proses fermentasi. Skripsi Jurusan Teknik
Kimia, Fakultas Teknologi Industri, Institut Sains dan Teknologi Al- Kamal, Jakarta.

Rizqi, A. F. 2013. Cara Pembuatan Pancake.http://c aramembuat123.blogspot.co.id/2013 /04/cara-membuat-pancake.html. Diakses tanggal 13 Januari 2017 pukul 20.13 WIB.

Roesmarkam, S., Suyamto, dan Suwono. 2002. Varietas Unggul Padi Tahan Tungro, Monograf Rakitan Teknologi. BPTP JawaTimur.

Suda, I., Oki, T., Masuda, M., Kobayashi, M., Nishiba, Y. dan Furuta, S. (2003). Review: Physiological functionality of purplefleshed seet potatoes containing anthocyanins and their utilization in foods. Japan Agricultural Research Quarterly 37: 167-173.

Widayanti, Fajar. 2008. Cara Menanam Padi Hingga Proses Menjadi Beras. CV. Sahabat. Klaten.

Wijayanti. K 2015. Eksperimen Pembuatan Kue Semprit Tepung Beras Merah. Skripsi . Program Studi Pendidikan Tata Boga. Fakultas Teknik Uiversitas Negri Semarang. Semarang.

Widjanarko, S. 2008. Efek pengolahan terhadap komposisi kimia dan fisik ubi jalar ungu dan kuning. http://simonbwidja narko.wordpress.com/2008/06/19/efekpengolahan-terhadap-komposisi-kimiafisik-ubi-jalar-ungu-dan-kuning/[10 Januari 2010].

Winarno, F. G. 2008. Bahan Tambahan Makanan. Gramedia, Jakarta. 